Section Editor

Robert C. Griggs, MD
Editors' Note: In the February 21, 2017, issue of Neurology ${ }^{\circledR}$, the American Academy of Neurology Burnout Task Force reported that $60 \%$ of American neurologists surveyed experienced at least one symptom of burnout. In the accompanying editorial, Dr. Bernat hypothesizes as to why neurologists are more prone to burnout than other similar specialties and suggests several actions to reverse the trend, including increasing patient care time and decreasing clerical work. In WriteClick this week, Dr. Goldenberg responds to this editorial to describe how engagement with organized medicine, on the county, state, and national levels, has benefited him personally by shifting his focus from criticism to problem-solving. Drs. Czempisz and Kunte make the case for mindfulness-based stress reduction techniques as a strategy to decrease physician burnout.

—Megan Alcauskas, MD, and Robert C. Griggs, MD

\section{LETTER RE: HOW CAN NEUROLOGISTS AVOID BURNOUT?}

James N. Goldenberg, Atlantis, FL: I read Dr. Bernat's editorial with interest. ${ }^{1}$ It is an excellent summary of the current health of our profession. An additional mitigation strategy, proven successful for me, is engagement with organized medicine. My professional journey took me from a county medical society to a state medical society and on to the American Academy of Neurology (AAN). In each venue, I find thoughtful, engaged physicians and dedicated, intelligent support staff. Clinical practice neurologists often spend their career in a rather isolated setting. When physicians do get together, the current practice environment fosters criticism. My dialogue has shifted from eloquent discontent in the hospital lunchroom to problemsolving in society meetings. I find engagement is often rewarded with positive feedback and the opportunity to contribute more meaningfully. Rather than reacting to changes forced upon me with a sense of helplessness, I feel empowered. I feel that I am shifting the landscape (albeit ever so slightly). I encourage Dr. Bernat and the AAN Burnout Task Force to actively promote
WriteClick ${ }^{\circledR}$ Editor's Choice

engagement with organized medicine as an option for neurologists to avoid burnout.

1. Bernat JL. How can neurologists avoid burnout? Neurology 2017;88:726-727.

(C) 2017 American Academy of Neurology

\section{LETTER RE: HOW CAN NEUROLOGISTS AVOID BURNOUT?}

Anne M. Czempisz, Hagen Kunte, Berlin: We read with interest the article by Dr. Bernat, ${ }^{1}$ which gave an overview on how to avoid or reduce burnout for neurologists. It is a good approach to recreate workflows and give space to meet the most demanding individual requirements. A great way to expand the interventions to promote mental well-being would be by adding mindfulness-based interventions. Goodman and Schorling ${ }^{2}$ published a pre-post observational study on mindfulness-based stress reduction for health care providers, with impressive results. The intervention was for a period of 8 weeks, ${ }^{2}$ which is a good index that rapid improvement of individual well-being is possible. Significant improvement was achieved on the emotional exhaustion, depersonalization, and personal accomplishment scales. ${ }^{2}$ This proposed approach is progressing toward a high-grade solution, including different ways to improve the health of neurologists. It remains to be seen if this approach can be implemented rapidly.

1. Bernat JL. How can neurologists avoid burnout? Neurology 2017;88:726-727.

2. Goodman MJ, Schorling JB. A mindfulness course decreases burnout and improves well-being among healthcare providers. Int J Psychiatry Med 2012;43: 119-128.

(C) 2017 American Academy of Neurology

\section{AUTHOR RESPONSE: HOW CAN NEUROLOGISTS AVOID BURNOUT?}

James L. Bernat, Lebanon, NH: I thank Dr. Goldenberg for the comment on my editorial. ${ }^{1}$ He explains how he, as a busy clinical neurologist, found meaning by representing colleagues in 
a series of professional medical societies. It is a wonderful testimony of the point made in the article by Busis et al. $^{2}$ that achieving personal engagement is a powerful preventive to burnout.

I also thank Czempisz and Kunte for the useful and valuable suggestion in response to my editorial. ${ }^{1}$
1. Bernat JL. How can neurologists avoid burnout? Neurology 2017;88:726-727.

2. Busis NA, Shanafelt TD, Keran CM, et al. Burnout, career satisfaction, and well-being among US neurologists in 2016. Neurology 2017;88:797-808.

(C) 2017 American Academy of Neurology

\section{CORRECTION}

Pharmacotherapy for diabetic peripheral neuropathy pain and quality of life: A systematic review In the Views \& Reviews article "Pharmacotherapy for diabetic peripheral neuropathy pain and quality of life: A systematic review" by J.M. Waldfogel et al., ${ }^{1}$ two studies (NCT01474772 and NCT01455415) were incorrectly referenced as unpublished, resulting in several errors. The second sentence in the Results under "Anticonvulsants vs placebo" should read "Our updated search identified 8 additional published RCTs as well as 2 unpublished RCTs with results." In figure 1, the sources of the studies were corrected, the order changed slightly, and the overall $I^{2}$ value changed from $80.8 \%$ to $80.1 \%$ (see the corrected figure below). Tables e-2 and e- 4 were updated to include the number of studies in updated search and number of studies with statistically insignificant results. The changes do not change the pooled effect size, conclusions, or strength of evidence. Corrected e-tables and e-references can be found with supplemental data at Neurology.org. The authors regret the errors.

\section{REFERENCE}

1. Waldfogel JM, Nesbit SA, Dy SM, et al. Pharmacotherapy for diabetic peripheral neuropathy pain and quality of life: a systematic review. Neurology 2017;88:1958-1967.

Figure 1 Meta-analysis of calculated standardized mean differences (SMD) for studies comparing pregabalin with placebo for pain outcome

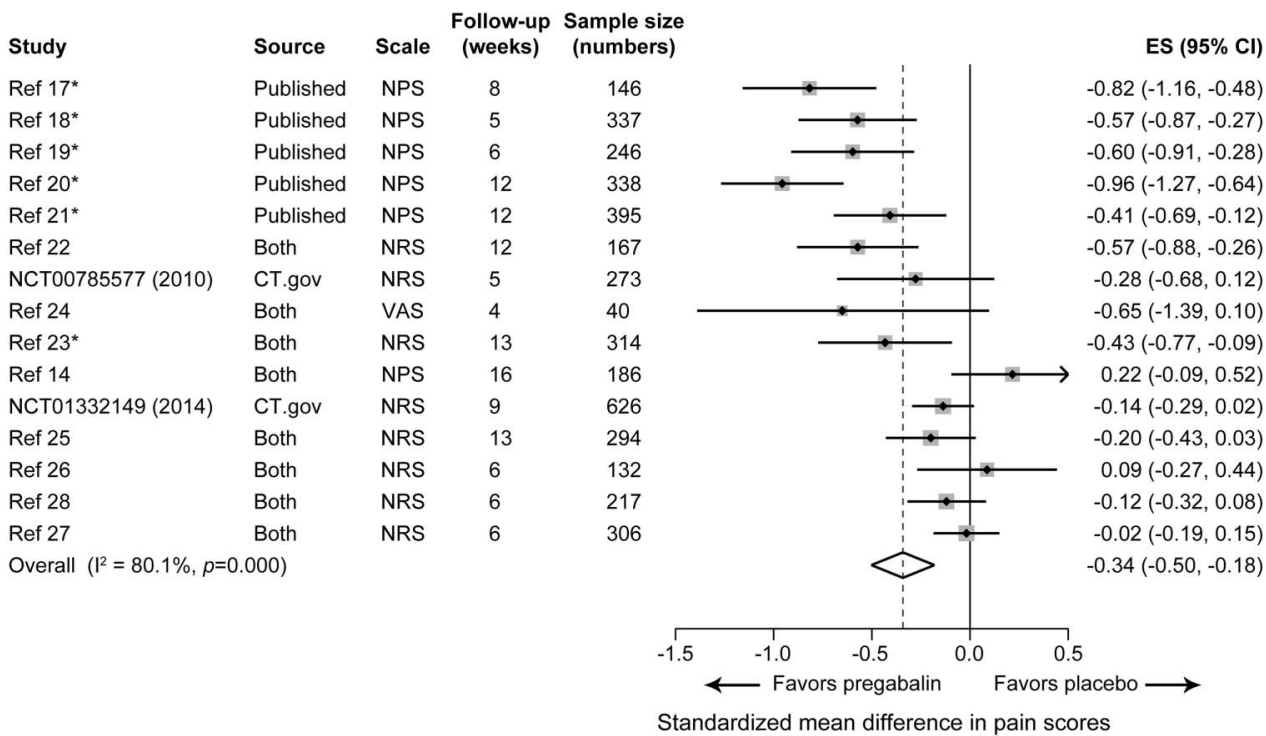

*Studies from the Griebeler et al. systematic review. Both = studies retrieved as a publication and from ClinicalTrials.gov; CT.gov $=$ studies retrieved from ClinicalTrials.gov; Published $=$ studies retrieved as a publication; $\mathrm{Cl}$ = confidence interval; NPS = Neuropathic Pain Scale; NRS = Numeric Rating Scale; VAS = Visual Analog Scale. 


\section{Neurology}

\section{Pharmacotherapy for diabetic peripheral neuropathy pain and quality of life: A systematic review \\ Neurology 2017;89;875 \\ DOI 10.1212/WNL.0000000000004323}

This information is current as of August 21, 2017

\begin{tabular}{|c|c|}
\hline $\begin{array}{l}\text { Updated Information \& } \\
\text { Services }\end{array}$ & $\begin{array}{l}\text { including high resolution figures, can be found at: } \\
\text { http://n.neurology.org/content/89/8/875.full }\end{array}$ \\
\hline References & $\begin{array}{l}\text { This article cites } 1 \text { articles, } 1 \text { of which you can access for free at: } \\
\text { http://n.neurology.org/content/89/8/875.full\#ref-list- } 1\end{array}$ \\
\hline Citations & $\begin{array}{l}\text { This article has been cited by } 1 \text { HighWire-hosted articles: } \\
\text { http://n.neurology.org/content/89/8/875.full\#\#otherarticles }\end{array}$ \\
\hline Permissions \& Licensing & $\begin{array}{l}\text { Information about reproducing this article in parts (figures,tables) or in } \\
\text { its entirety can be found online at: } \\
\text { http://www.neurology.org/about/about_the_journal\#permissions }\end{array}$ \\
\hline Reprints & $\begin{array}{l}\text { Information about ordering reprints can be found online: } \\
\text { http://n.neurology.org/subscribers/advertise }\end{array}$ \\
\hline
\end{tabular}

Neurology ${ }^{\circledR}$ is the official journal of the American Academy of Neurology. Published continuously since 1951, it is now a weekly with 48 issues per year. Copyright @ 2017 American Academy of Neurology. All rights reserved. Print ISSN: 0028-3878. Online ISSN: 1526-632X.

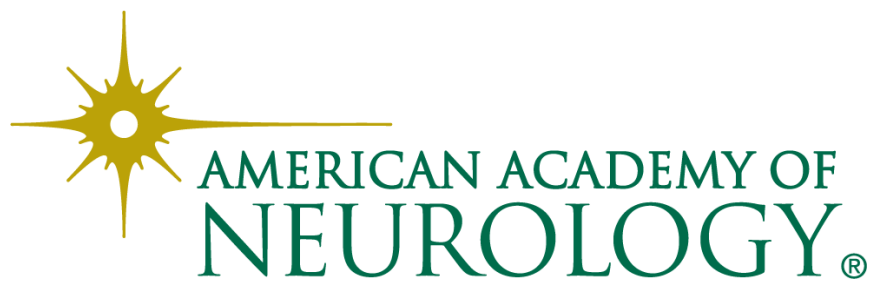

